Trinity University

Digital Commons @ Trinity

English Faculty Research

English Department

9-2008

\title{
The Mother Church: Mary Baker Eddy and the Practice of Sentimentalism
}

Claudia Stokes

Trinity University, cstokes@trinity.edu

Follow this and additional works at: https://digitalcommons.trinity.edu/eng_faculty

Part of the English Language and Literature Commons

\section{Repository Citation}

Stokes, C. (2008). The mother church: Mary Baker Eddy and the practice of sentimentalism. The New England Quarterly, 81(3), 438-461. doi: 10.1162/tneq.2008.81.3.438

This Article is brought to you for free and open access by the English Department at Digital Commons @ Trinity. It has been accepted for inclusion in English Faculty Research by an authorized administrator of Digital Commons@ Trinity. For more information, please contact jcostanz@trinity.edu. 


\title{
The Mother Church: Mary Baker Eddy and the Practice of Sentimentalism
}

\author{
CLAUDIA STOKES
}

\begin{abstract}
CONSIDER the following: a young New England woman of a strict Calvinist upbringing falls in love with a dashing soldier, but he dies suddenly just months after their marriage, leaving her penniless and pregnant. With no income or home of her own, she bounces from relative to relative, receiving little hospitality or financial assistance. Unable to provide for her son, she is forced to give him up, and he falls into the hands of cruel guardians in the distant West who refuse to educate him. Desperate to support herself, the disconsolate mother takes up her pen, writing poetry and sorrowful essays for local journals and receiving rejection notices from national periodicals such as Godey's Lady's Book. After years of poverty, loneliness, and poor health, she experiences a spiritual epiphany while reading the Bible during the course of a grave illness and soon transmutes that revelation into physical vitality, prosperity, a happy marriage, and a new form of literary output. In so doing, she becomes a role model and figure of adoration for countless readers, most of them women.
\end{abstract}

Those acquainted with American literary sentimentalism will find the plot line familiar. But although it redounds with

I thank James Ivy for his significant contribution to this essay. I also thank the Office of Academic Affairs at Trinity University for a summer grant in support of this essay. In addition, I wish to thank the welcoming and generous staff and congregation of the First Church of Christ, Scientist, of San Antonio, Texas, for their help with my research. Finally, I wish to thank the inestimable Linda Smith Rhoads for her generosity and integrity.

The New England Quarterly, vol. LXXXI, no. 3 (September 2008). (C) 2008 by The New England Quarterly. All rights reserved. 
allusions to that nineteenth-century genre, the narrative is not a literary creation at all but is, instead, the life story of Mary Baker Eddy (1821-1910), the founder of Christian Science and one of the most successful women writers in a century replete with successful women writers. Produced in the midnineteenth century, sentimental works like Susan Warner's The Wide, Wide World (1850) and Maria Susanna Cummins's The Lamplighter (1854) recounted the trials of a solitary young heroine who, forced to make her own way in the world, must endure severe personal loss and tame her temper to achieve Christian salvation, economic independence, and, more often than not, marriage to a man who is both Christian and well-todo. ${ }^{1}$ Eddy's need to give up her child, for example, invokes the trials of Ruth Hall, eponymous heroine of Sara Willis Parton's autobiographical novel (1855); similarly, her spiritual awakening conjoined with material prosperity and social status recalls the treasures John Humphreys presents to his virtuous young bride, Ellen Montgomery, at the close of The Wide, Wide World.

The similarities between her life and the conventions of sentimental narrative were not lost on Eddy, an avid reader of the genre. ${ }^{2}$ After she was widowed in 1844 but before the

\footnotetext{
${ }^{1}$ Nina Baym similarly characterizes this central narrative. Sentimentalism relates "one particular story about women. They chronicle the 'trials and triumphs' . . of a heroine who, beset by hardships, finds within herself the qualities of intelligence, will, resourcefulness, and courage sufficient to overcome them" (Woman's Fiction: A Guide to Novels by and about Women in America, 1820-70, 2nd ed. [Urbana: University of Illinois Press, 1993], p. 22).

${ }^{2}$ Ann Douglas (Terrible Honesty: Mongrel Manhattan in the 1920's [New York: Farrar Straus Giroux, 1995], p. 161), for example, claims that Eddy in her girlhood had been a particular fan of the novels of Emma Southworth, one of the leading women writers of the nineteenth century. Gail Parker remarked on this resemblance nearly forty years ago, commenting, "During most of her long life [Eddy] directed her energies into playing the role of sentimental heroine become divine" (Gail Parker, "Mary Baker Eddy and Sentimental Womanhood," New England Quarterly 43 [March 1970]: 17). Parker's essay is the only source I have been able to locate that situates Eddy within the context of sentimentalism. However, Parker is unreservedly contemptuous both of Eddy and of sentimentalism, and she aligns the two chiefly to impugn Eddy's integrity and status. Though she briefly discusses the sentimentalism of Eddy's poem "Meeting of My Departed Mother and Husband," Parker's treatment of sentimentalism is largely impressionistic and general. Governed by the parapsychoanalytic methods common to scholarship of the 1960 a and 70 , the essay is primarily concerned with detecting sexual frustration, sublimation, and rapacious ambition in Eddy's life. Thus, it proved to be of limited use to my own inquiry.
} 
1870 spiritual epiphany that prompted her to write Science and Health with Key to the Scriptures, the foundational text of the Christian Science movement, Eddy, like authors such as Willis, Louisa May Alcott, and Emma Southworth, ${ }^{3}$ tried to wring financial advantage out of her personal misfortunes by writing about them in the sentimental idiom and submitting those works for publication. ${ }^{4}$ Even later, despite her theological renunciation of the material world and her renown as a spiritual leader, Eddy never sacrificed her attachment to sentimentalism but continued to write and circulate verse in the sentimentalist vein. Her sustained commitment to sentimentalism is, however, no mere literary curiosity, a reflection of an amateur's taste. Rather, Eddy carefully and conscientiously imported sentimentalism's formulas and beliefs into her spiritual doctrine at the same time as she presented her own life as the unfolding of a triumphal narrative of sentimental motherhood. In the process, she created a powerful new religion that appealed to a generation of women eager to reap the rewards of having spiritually defeated suffering.

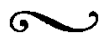

As Joanne Dobson has shown, nineteenth-century American sentimental narratives were not as emotionally overwrought as some critics have charged but, in truth, had a basis in the "all-too-common social tragedies and political outrages stemming from the failure of [the period's] society to care

\footnotetext{
${ }^{3}$ The story of woman's spiritual triumph over poverty parallels not only the plot of sentimental literature but also the biographies of many sentimental writers themselves, including Louisa May Alcott, Emma Southworth, and Sara Willis Parton. Moreover, in Parton's Ruth Hall, Alcott's Little Women (1869), and Augusta Evans's St. Elmo (1867), the destitute heroines are also writers.

${ }^{4}$ Assuming the pose of a celebrated authoress, Eddy cultivated her reputation with an extravagant vocabulary and word play. As one observer related, Eddy was introduced to noted mind-cure healer Phineas Parkhurst Quimby "as 'the authoress,' and her manner was extremely polite and ingratiating. She wore a poke bonnet and an oldfashioned dress, but my impression was that her costume was intended to be a little odd, as in keeping with her 'literary' character." Quoted in Georgine Milmine, The Life of Mary Baker G. Eddy and the History of Christian Science (1909; reprinted, Grand Rapids, Mich.: Baker Books House, 1971), p. $5^{6 .}$
} 
for the disconnected." 5 Sentimentalism did not just trace such tragedies but offered readers a protocol for managing agony and loss, and Christian Science's considerable success can be attributed in part to its use of that same protocol as it sought to provide consolation for the ravages of the body. It is no accident that the overwhelming majority of Christian Scientist devotees at the turn of the century were women, for Eddy not only explicitly appealed to a distinctly feminine brand of suffering but, in adopting much of the imagery and many of the conventions of sentimentalism, also attracted women already familiar with those devices through the medium of literature. ${ }^{6}$ As formulated by Eddy, Christian Science carried on the work of sentimentalism long after critics and literary historians had deemed it obsolete. Indeed, an analysis of Eddy's writings reveals that the indigenous, nineteenth-century American religion she founded typifies the "concrete social institutionalization" of sentimentalism that Laura Wexler has described. ${ }^{7}$

Christian Science is, of course, best known for its rejection of conventional medicine in favor of prayerful meditation, a practice rooted in the radical subordination of matter to spirit. Matter, Eddy wrote, is merely an "illusion." "Man is not matter; he is not made up of brain, blood, bones, and other material elements." Corporeal suffering, she argued, derives not from the degradation of the body, as traditional medicine contends, but from a belief in matter. The mind, Eddy claimed, has the

5 Joanne Dobson, "Reclaiming Sentimental Literature," American Literature 69 (June 1997): 272. She provides a survey of the criticisms leveled at sentimentalism on p. 282.

${ }^{6}$ Critic Elbert Hubbard confirmed this gendered appeal in 1908 with his observation that "Christian Science is a woman's science" (Little Journeys to the Homes of Great Teachers-Mary Baker Eddy [East Aurora, N.Y.: Roycrofters, 1908], p. 138). Eddy marketed Christian Science to women through circulars in which she described herself as a professor of obstetrics and promised to heal various female-gendered health problems, such as labor pains. According to Gillian Gill (Mary Baker Eddy [Cambridge, Mass: Perseus, 1998], pp. 284-85), Eddy's most recent biographer, the majority of those who claimed to have been healed by Christian Science methods had complained of gynecological problems.

${ }^{7}$ Laura Wexler, "Tender Violence: Literary Eavesdropping, Domestic Fiction, and Educational Reform," Culture of Sentiment: Race, Gender, and Sentimentality in Nineteenth-Century America, ed. Shirley Samuels (New York: Oxford University Press, 1992), p. 19 . 
power to create circumstances that confirm its own beliefs. Just as a patient who places his faith in medical science may feel cured by a placebo, conversely, Eddy wrote, "a sick body is evolved from sick thoughts." To trust in matter is to make oneself vulnerable to its frailties and impermanence, and so one need only eliminate that trust to achieve health. As Eddy declared, "when one's false belief is corrected, Truth sends a report of health over the body."

Christian Science doctrine has some obvious biblical antecedents, as in the Gospel stories of the faith healing practiced by Jesus and his disciples, as well as roots in Puritan theology, which considered the material world to be but a temporary condition that obstructed access to the real world, the afterlife of the spirit. ${ }^{9}$ By the time Eddy issued Science and Health in the mid 1870s, however, that Calvinist belief had fallen out of favor in mainstream Protestantism, and American popular culture was being overrun by numerous movements-among them eugenics, anthropology, and social reform-that sought to interpret the body, thereby concretizing it. ${ }^{10}$ The sheer incongruity of Christian Science in the materialistic welter of Gilded Age culture has prompted some historians to

\footnotetext{
${ }^{8}$ Mary Baker Eddy, Science and Health with Key to the Scriptures (Boston: First Church of Christ, Scientist, 1994), 475:6-7; 260:20-21; 194:89.

${ }^{9}$ Although many Protestant denominations emphasized such material experiences as work and the acquisition of wealth, Max Weber has distilled their world view as a combination of the dual beliefs in "the absolute transcendentality of God and the corruption of everything pertaining to the flesh," a theological synthesis that resulted in "the entirely negative attitude of Puritanism to all the sensuous . . . elements in culture and in religion because they are of no use toward salvation and promote sentimental illusions and idolatrous superstitions" (The Protestant Ethic and the Spirit of Capitalism, trans. Talcott Parsons [New York: Scribner's, 1976], p. 105).

${ }^{10}$ Rather than denounce material experience as illusory and an enticement to sin, as their Puritan predecessors had, mainstream Protestant sects in the late century, spearheaded by the socially conscientious work of such prominent ministers as Henry Ward Beecher and Dwight Lyman Moody, instead turned their attention toward works that communicate the seriousness with which they perceived material, bodily experience. Whether through pulpit exhortations against poverty and social inequality or through the urban ministerial work of tending to the needs of immigrants and the poor, Protestantism in the late century attempted to ameliorate the bodily, material experiences of its congregants not by repudiating the existence of this domain but by striving to make improvements to it, thereby reifying what Eddy sought to discredit. See Sydney E. Ahlstrom, A Religious History of the American People (New Haven: Yale University Press, 1972), pp. 731-62.
} 
characterize Eddy as the pioneering popularizer of ideas that would course through later phenomena such as the New Thought movement of the late century and Norman Vincent Peale's blockbuster The Power of Positive Thinking (1952). ${ }^{11}$ Such a genealogy fails, however, to attend to the ecumenical medium of sentimental literature.

Decades before Eddy drafted a philosophy of mind-cure, sentimental writers had been circulating texts that rehearsed the beneficial consequences of adjusting one's beliefs and attitudes. Although sentimental heroines typically had little power to alter their woeful circumstances, by correcting their attitudes, novelists such as Warner and Cummins suggested, sufferers could effect immediate change, whether relief from worldly cares, increased physical attractiveness, or the arrival of serendipitous good fortune. This conviction that even the lowly could better their lives by controlling their thoughts became the cornerstone of Christian Science doctrine.

In addition, sentimental literature constituted Christian piety as fundamentally incompatible with the glorification of the body. ${ }^{12}$ For example, Harriet Beecher Stowe's Uncle Tom's Cabin (1851) investigates at length the spiritual perils that befall those who, like apostate slave owner Augustine St. Clare, literally invest in the human body via the slave trade. Likewise, two of the novel's iconic scenes-the deaths of Little Eva and of Uncle Tom-challenge the eschatological status

\footnotetext{
${ }^{11}$ Beryl Satter, Each Mind a Kingdom: American Women, Sexual Purity, and the New Thought Movement, 1875-1920 (Berkeley: University of California Press, 1999), p. 6. Satter's thoughtful and important work adopts a position toward Christian Science that is typical of scholarship over the last half century. Christian Science has received little scholarly attention in recent decades, but those texts that do mention it usually characterize it as the popularizer of the mind-cure that would flourish in the New Thought movement and psychoanalysis. See Douglas, Terrible Honesty, pp. 16o-66, and Gail Parker, Mind Cure in New England: From the Civil War to World War I (Hanover, N.H.: University Press of New England, 1973).

${ }^{12}$ Shirley Samuels has described sentimentalism as "a project about imagining the nation's bodies and the national body," a remark that equally describes Christian Science in its adaptation and elaboration of sentimental female bodilessness. See her intro. to The Culture of Sentiment: Race, Gender, and Sentimentality in Nineteenth-Century America (New York: Oxford University Press, 1992), p. 3. See also Marianne Noble, The Masochistic Pleasures of Sentimental Fiction (Princeton: Princeton University Press, 2000), pp. 29-35.
} 
of the body in the characters' willing, joyful abandonment of their physical selves for spiritual salvation, just as earlier they had refused to allow bodily suffering-whether by illness or abuse-compromise their faith. ${ }^{13}$

Cummins's novel The Lamplighter displays similar doubts about the body as a reliable index of a character's true nature, which instead is more accurately registered in the immaterial traits of virtue and temperament. ${ }^{14}$ In the novel the heroine, homely Gerty Flint, challenges beautiful Isabel Clinton for the affections of Willie Sullivan. Isabel—or "Belle," as she is called throughout the novel—is revealed to be calculating, weak, and spiteful, whereas Gerty's selflessness and kindness render her attractive. The shortening of Isabel Clinton's name to Belle serves as a tip-off that a larger metaphysical struggle is being staged in the rivalry for Willie's notice, with the body and its allures pitted against virtue, character, and spirit. Nina Baym has noted as much in her observation that this recurring competition between the sentimental heroine and the belle in nineteenth-century women's literature constitutes a kind of sentimental psychomachia in which the Spirit and the Body vie for dominance, a contest that is also at the heart of Christian Science. ${ }^{15}$

\section{$\sim$}

As these works attest, sentimentalists had long claimed that the overvaluation of the corporeal at the expense of the spiritual was responsible for suffering and that spiritual enlightenment

\footnotetext{
${ }^{13}$ Samuels describes this phenomenon: "the suffering female child whose potentially grotesque death is radically spiritualized [and] . . . the brutally beaten slave whose triumph is shown to be an escape from a transcendence of the body which has been the cause of his suffering" (intro. to Culture of Sentiment, p. 5).

${ }^{14}$ The character Emily Graham is perhaps the most obvious example of the empty signifier of the body: though blind, she has the clearest insight and strongest perceptive powers of any character in the novel, much like a sentimental Tiresias, and bodily powers such as sightedness function chiefly as impediments to the detection of the truth. In this way, the novel expresses great distrust of physical beauty, which it presents as an accident of birth that in no way communicates anything about a person's true nature; rather than functioning as a marker of exceptionality or worth, it is an unreliable, meaningless covering that offers no commentary on the contents it conceals.

${ }^{15}$ Baym, Woman's Fiction, pp. xxxvii-ix.
} 
alone offered relief from worldly anguish. Thus, the theological ideas at the heart of Christian Science had been in circulation for decades among women of Eddy's generation and demographic group. But the full depth of Eddy's reliance on sentimentalism is most apparent in Christian Science's ubiquitous rhetoric of beset motherhood. As evidenced in the saintly, deceased mother for whom the heroine yearns in The Wide, Wide World and the special ethical force that maternal love exerts in Uncle Tom's Cabin, the mother serves as the paramount spiritual custodian in sentimental literature, one who both teaches and exemplifies the virtues of Christian charity and selflessness. Though sentimentalism figures the mother-child bond as a worldly facsimile of human beings' relationship to a loving God, that bond is typically threatened by external forces, like poverty, conspiracy, and death. As the sentimental plot unfolds, the daughter struggles to be reunited with the absent mother, the ultimate object of desire; the mother, however, tends to remain elusive, and the daughter must often be content with simply adopting the mother's Christian faith or learning the true story of the mother's own sufferings.

The sentimental trope of beset motherhood is pervasive in Christian Science lore, and in Eddy's adaptation, it became the founding myth of Christian Science. In her biography, she assumed the role of both isolated sentimental daughter, separated from her beloved mother and forced to make her own way in the world, and the careworn sentimental mother who provides loving spiritual guidance to her young. The pattern is evident in Eddy's 1891 memoir, Retrospection and Introspection, in which she depicts both her own mother and herself as the embodiments of sentimental maternity. For example, in writing about her mother, Abigail Ambrose Baker, Eddy quotes from the Rev. Richard S. Rust's funeral eulogy to characterize her mother's selflessness and spiritual stewardship:

As a mother, she was untiring in her efforts to secure the happiness of her family. She ever entertained a lively sense of the parental obligation, especially in regard to the education of her children. The oft-repeated impressions of that sainted spirit, on the hearts of those 
especially entrusted to her watch-care, can never be effaced, and can hardly fail to induce them to follow her to the brighter world. Her life was a living illustration of Christian faith. ${ }^{16}$

In relating this description of her late mother in the early pages of her memoir, Eddy simultaneously positions herself as the sentimental heroine grieving the death of her "sainted" mother and as her mother's natural successor, for, as Rust comments, Abigail Baker's mothering was such that her children "can hardly fail . . . to follow her to the brighter world" of Christian salvation. Later in the memoir, Eddy gives proof of the rightfulness of her succession to the role of sentimental mother as she recounts her own suffering. "I had no training for self-support," she writes, "and my home I regarded as very precious. The night before my child was taken from me, I knelt by his side throughout the dark hours, hoping for a vision of relief from this trial." She closes the vignette by quoting several lines from her poem "Mother's Darling":

Thy smile through tears, as sunshine o'er the sea,

Awoke new beauty in the surge's roll!

Oh, life is dead, bereft of all, with thee,-

Star of my earthly hope, babe of my soul. ${ }^{17}$

"Mother's Darling" revisits the familiar sentimental scenario of mother-child separation, but by including the poem in her memoir, Eddy envelops a poignant biographical moment within the sentimental aesthetic to present her own life as a literary artifact.

In circulating sentimentalized narratives of her own life story, Eddy clearly succeeded in making herself recognizable and appealing to her supporters, but she also left an opening for critics to evaluate the historical legitimacy of her claims. Over the last century, Eddy was the subject of dozens of biographies seeking to square her markedly literary

\footnotetext{
${ }^{16}$ Mary Baker Eddy, "Retrospection and Introspection," Prose Works Other Than "Science and Health with Key to the Scriptures" (Boston: Trustees under the Will of Mary G. Baker Eddy, 1925), pp. 5-6.

${ }^{17}$ Eddy, "Retrospection and Introspection," p. 20.
} 
self-presentation with the archival evidence. Critics intent on discrediting her doctrine and pastoral authority often did so by attacking her autobiographical claims and characterizing Eddy as the antithesis of the sentimental mother: conniving, greedy, selfish, and hysterical. ${ }^{18}$ Meanwhile, ardent supporters published biographies, some verging on hagiography, sympathetic to Eddy's version of her life story. ${ }^{19}$ To stem the tide of biographically based assaults, the Christian Science Church made Eddy's papers inaccessible to researchers for nearly a century, thereby leaving these scholarly disputes unresolved, though the recent opening of her archives in the Mary Baker Eddy Library in Boston will undoubtedly yield valuable new information to this ongoing debate.

This century-old quarrel about the accuracy of biographical and autobiographical accounts of Eddy's life has tended, however, to overlook the larger literary historical value of her self-presentation. Though her personal life may not have corresponded perfectly with the standards of sentimental maternity, Eddy's public image and work amply document the performative, institutional uses of those conventions. At its most basic level, Eddy's life story demonstrates how sentimental readers absorbed sentimental archetypes into their spiritual beliefs, construed themselves through the lens of sentimental prototypes, and sought consolation in the sentimental narrative's resolution of worldly travails. Moreover, in promoting her own life story, Eddy breathed new life into these literary tropes with the effect that sentimental conventions acquired the standing of religious iconography and doctrine.

\footnotetext{
${ }^{18}$ Examples of such work include the deeply critical series of articles on Eddy in McClure's Magazine, 1907-8; Edwin Franden Dakin, Mrs. Eddy: The Biography of a Virgin Mind (New York: Blue Ribbon, 1930); Ernest Sutherland Bates and John V. Dittemore, Mary Baker Eddy: The Truth and the Tradition (New York: Knopf, 1932); and Parker, "Mary Baker Eddy and Sentimental Womanhood."

${ }^{19}$ Such works include Fleta Campbell Springer, According to the Flesh (New York: Coward-McCan, 1930); Robert Peel, Mary Baker Eddy: The Years of Discovery, 2 vols. (New York: Holt, Rinehart and Winston, 1966); and Stephen Gottschalk, Rolling away the Stone: Mary Baker Eddy's Challenge to Materialism (Bloomington: Indiana University Press, 2006).
} 


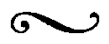

Eddy's transformation of sentimental formula into Christian Science typology is particularly apparent in her poem "The Mother's Evening Prayer." Said to have been composed in the 1840 o before she sent away her only child, the poem is plainly autobiographical in its depiction of a pivotal moment in Eddy's life. The "prayer," comprised of five rhyming iambic quatrains, portrays a speaker who beseeches God to safeguard her child in her absence.

O Gentle presence, peace and joy and power;

O Life divine, that owns each waiting hour,

Thou Love that guards the nestling's faltering flight!

Keep Thou my child on upward wing tonight.

Love is our refuge; only with mine eye

Can I behold the snare, the pit, the fall:

His habitation high is here, and nigh,

His arm encircles me, and mine, and all.

O make me glad for every scalding tear,

For hope deferred, ingratitude, disdain!

Wait, and love more for every hate, and fear

No ill,-_since God is good, and loss is gain.

Beneath the shadow of His mighty wing;

In that sweet secret of the narrow way,

Seeking and finding, with the angels sing:

"Lo, I am with you alway," watch and pray.

No snare, no fowler, pestilence or pain;

No night drops down upon the troubled breast,

When heaven's aftersmile earth's tear-drops gain,

And mother finds her home and heav'nly rest. ${ }^{20}$

Like "Mother's Darling," “The Mother’s Evening Prayer" firmly plants Eddy (in the guise of the poem's speaker) within sentimentalism's familiar scenario of parent-child separation. In calling upon God's help in her time of need, Eddy casts herself as

${ }^{20}$ Mary Baker Eddy, "Mother's Evening Prayer," Poems (Boston: Trustees under the Will of Mary Baker G. Eddy, 1910), pp. 4-5. 
the pious sentimental mother who remains her child's spiritual steward even at a remove and whose parenting responsibilities are assumed, in her stead, by no less a protector than God. And in imploring that God "make her glad for every scalding tear, / For hope deferred, ingratitude, disdain!” Eddy accepts the recognizable sentimental role of the willing sufferer, striking a posture of joyful submission in the face of grave trial.

In all these ways, "The Mother's Evening Prayer" documents Eddy's fluency in sentimental convention as well as her appropriation of sentimental maternity in depicting her own life. Although she wrote the poem decades before the revelation that led to the founding of Christian Science, Eddy evidently thought that it was relevant to Christian Science worship, for years later she had it adapted for inclusion in the Christian Science hymnal, where, set to six different tunes, it can still be found as hymns 207-12. Its setting to six different tunes suggests that "The Mother's Evening Prayer" was intended to enjoy especially heavy rotation, an intention Eddy ensured with her stipulation in church bylaws that it, as well as other hymns she authored, be sung during Sunday services at least once a month. The biographical character of "Mother's Evening Prayer" would have been readily apparent to Christian Scientists not only because church bylaws required that Eddy's authorship be publicly announced before the hymn was sung but also because Eddy was widely called Mother by her followers, a practice evoked by the poem's title.

When sung publicly, "Mother's Evening Prayer" reenacts the scene of familial separation essential to sentimentalism, and it commemorates maternal grief. But in such an ecclesiastical setting, many of these sentimental conventions acquire new doctrinal overtones. For example, the third stanza, in which the persona resolves to become a willing sufferer, closes with the assertion that she will "fear / No ill,--since God is good, and loss is gain." This poetic elaboration on the sentimental metamorphosis of grief into joy echoes the Christian Science belief in the rewards of renouncing the physical world-that is, the conviction that "loss is gain." As it traces the speaker's efforts to embrace her travails and thereby to triumph over 
them, the poem also records her readiness to undergo the attitudinal adjustment that both sentimentalism and Christian Science credited with the power to effect change. Moreover, because the poem is constructed, at a formal level, as a prayer for comfort and protection, it affirms the core Christian Science tenet that suffering can be relieved through prayer and spirituality, as when the speaker asserts that in God there is "No snare, no fowler, pestilence, or pain." In portraying a mother's entreaty and attendant consolation, the poem uses sentimental convention to dramatize a scene of Christian Science healing in which prayer affords comfort and relief. And in invoking Eddy's own personal history, the poem simultaneously depicts the very starting point of Christian Science, her originary revelation that prayer can effect healing. Thus, the poem illustrates how sentimental convention in Eddy's hands came to denote Christian Science doctrine.

"Mother's Evening Prayer" is one prominent instance among many in which Eddy presented herself as a sentimental mother, but the public, ritualistic life of such texts enabled her to fashion herself into a universal sentimental mother, a loving maternal figure and spiritual guide to all. To consolidate this association, she encouraged her followers to call her Mother Mary and in turn referred to them as her children, as with her poem "A Verse," in which she employs metaphors of mothers and children to characterize her relations with congregants. ${ }^{21}$ Motherhood constitutes the central metaphor of authority in Christian

${ }^{21}$ The poem reads as follows:

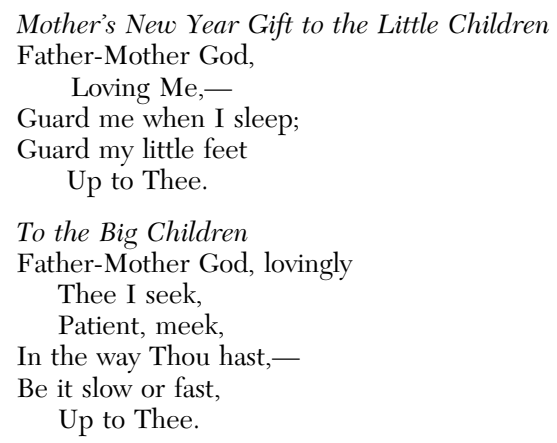


Science, a term used to designate Eddy herself, God, and the Boston headquarters of Christian Science, which she dubbed the Mother Church, a title still in use. ${ }^{22}$ When the building was completed in 1894, it contained a chamber reserved for Eddy alone called "Mother's Room," a space whose homely title domesticates Eddy's authority within this maternal context. Similarly, Eddy broke with the Christian convention of a paternalistic God and instead promoted a hermaphroditic deity who possessed both maternal and paternal characteristics and whom she dubbed "Father-Mother God."

\section{$\sim$}

Eddy's maternal rhetoric was widely recognized as unoriginal during her lifetime, and she was accused of drawing too liberally from a different well of female-oriented Christian spirituality, Shakerism. The similarities between the two faiths are considerable. Shakerism was also founded by a charismatic female leader, Ann Lee, who likewise invited her followers to call her Mother. The Shakers dubbed their central church the "Mother Church," a fact not lost on Eddy's critics, who observed that the Shakers had conceived of a dual-gender God, also described as Father-Mother, long before the emergence of Christian Science. Both Eddy and Lee claimed healing powers, characterized themselves as Christ's female successor, and identified with the woman of the Apocalypse in the New Testament Book of Revelation. The two faiths also favored silent meditation over spoken prayer and shared a deep skepticism

Mary Baker Eddy, "A Verse," Poems including "Christ and Christmas" (Boston: Trustees under the Will of Mary G. Baker Eddy, 1938), p. 69.

${ }^{22}$ The official website of Christian Science is found at the URL www.themotherchurch.org. Eddy renounced the title Mother after Mark Twain publicly excoriated her for it in Christian Science, with Notes Containing Corrections to Date (New York: Harper, 1907), p. 48. A reference to this humiliating episode endures in the Church Manual, the record of church bylaws, art. 22, sec. 1: "loyal Christian Scientists had given to the author of their textbook, the Founder of Christian Science, the individual, endearing term of Mother. . . . In the year nineteen hundred and three and after, owing to the public misunderstanding of this name, it is the duty of Christian Scientists to drop the word mother and to substitute Leader, already used in our periodicals" (Mary Baker Eddy, Manual of the Mother Church The First Church of Christ Scientist, in Boston, Massachusetts, 89th ed. [Boston: First Church of Christ, Scientist, 1936], pp. 64-65). 
about the theological status of the body, a concern that led the Shakers to institute celibacy and Eddy to renounce the existence of the body altogether.

In the early twentieth century, Eddy's detractors made much of such similarities. From an infamous series of articles that ran in McClure's Magazine in 1907-8 to later works like Mary Baker Eddy: The Truth and the Tradition, a 1932 biography by Ernest Sutherland Bates and John V. Dittemore, critics characterized Eddy as a fraud who had appropriated Mother Ann's image and doctrine for her own material gain. There is, however, little historical evidence that Eddy willfully relied on Shakerism, and although she conceded her likeness to Mother Ann, she responded to the McClure's accusations with a straightforward disavowal, "I never was especially interested in the Shakers." 23

In 1929 Edwin Dakin attempted to build a case against Eddy by citing a letter written by sixteen-year-old Mary Baker in which she expressed her desire to visit a nearby Shaker village; she was, she said, refused permission "by [her] superiors because it would be a profanation of the Sabbathe." 24 The letter evidences, however, less an attraction to Shakerism than to the "gentleman recently from Boston" who invited her on the expedition; indeed, the discussion that immediately follows, of a Mr. Bartlett whom she had met at a wedding, shows that, at the time the young woman wrote the letter, she was more interested in men than in Shakers. Eddy's later biographer Robert Peel commented that such outings to Shaker villages were "a usual thing for the young people to do," and he convincingly argued that the Shakers would have been familiar figures in Eddy's childhood hometown of Sanbornton, New Hampshire, for they regularly sold their handicrafts there and in other towns nearby the Shaker village at Canterbury. ${ }^{25}$ Present-day scholars such as Susan Hill Lindley have likewise found no substantial evidence that Eddy deliberately appropriated Shaker doctrine

${ }^{23}$ Gill, Mary Baker Eddy, p. 48; Mary Baker Eddy, "Reply to McClure's Magazine," The First Church of Christ Scientist and Miscellany (Boston: Trustees under the Will of Mary Baker G. Eddy, 1941), 313:21.

${ }^{24}$ Dakin, Mrs. Eddy, p. 13.

${ }^{25}$ Peel, Eddy: The Years of Discovery, p. 53. 
and iconography, but Lindley concludes, like Peel, that Eddy was very likely exposed to some aspects of Shaker culture due to her proximity to the Shaker community. ${ }^{26}$

Although Eddy's rhetoric of matriarchy may have had specific regional and institutional antecedents, other material sources also undoubtedly shaped her metaphors and public image. Motherhood was central to Eddy's professional reputation from the outset, when she worked as a healer specializing in obstetrical and gynecological maladies such as labor pains and infertility. She was credible as a mother figure, too, because of her own biological motherhood, a condition resolutely discouraged in Shakerism and one that she publicized through her forays into literary sentimentalism. Indeed, by the time Christian Science attained national prominence at the turn of the century, Shakerism had dwindled to a single colony, and Eddy's success owed less to this minority denomination than to her enlistment of scenarios, structures of feeling, and discourse rendered familiar and appealing in sentimental literature.

While Mother Ann Lee in all probability had some influence on Eddy, the sentimental image of the ethereal, loving mother who provides spiritual guidance to the multitudes ultimately derived from the Virgin Mary, the Christian prototype of selfless maternal love. As a central figure of Catholic worship, Mary was anomalous to the Protestantism intrinsic to sentimentalism, but she was, nonetheless, the exemplar of female piety and submission celebrated in sentimental literature. As Laura Wexler's study of sentimental photography shows, the Virgin Mary served as sentimentalism's model of female devotional decorporealization, as manifest in her asexuality and postmortem spiritualization. ${ }^{27}$ Taking Mary as its doctrinal

\footnotetext{
${ }^{26}$ Susan Hill Lindley, "The Ambiguous Feminism of Mary Baker Eddy," Journal of Religion 64 (July 1984): 322-23. It would seem, however, that the Shaker interest in Christian Science is more verifiable. In his history of Shakerism in the United States, Stephen Stein has documented the enthusiasm many Shakers showed for Christian Science belief and healing practices. See The Shaker Experience in America: A History of the United Society of Believers (New Haven: Yale University Press, 1992), p. 326.

${ }^{27}$ Laura Wexler, "Seeing Sentiment," Tender Violence: Domestic Visions in an Age of U.S. Imperialism (Chapel Hill: University of North Carolina Press, 2002), pp. 52-93; see also Noble, Masochistic Pleasures, pp. 33-35.
} 
ideal, sentimentalism similarly construed bodily renunciation as evidence of female Christian piety, depicting the repudiation of bodily appetite, sensuality, and individual personhood as signals of the sentimental heroine's devotion. Thus, the Virgin Mary provided Eddy with the earliest model for her public persona as a sentimental mother as well as a source for the theological cornerstone of Christian Science doctrine, namely, the renunciation of the body.

Eddy was fully aware of her debt to Mary, whom she identified as the original author of Christian Science belief. In the 1875 first edition of Science and Health, for example, Eddy credited Mary with having first recognized the falsity of what Eddy called "Substance" and with valuing the innate immateriality of divinity. In the much-maligned style of her early theological prose, Eddy wrote,

Those who were taught by [Jesus] the science of being reached the glorious perception that God is the only author of man. The virgin mother first conceived this idea of God and named it Jesus; the illumination of spiritual sense had put to silence personal sense with Mary, thus mastering material law and establishing through demonstration that God is the father of man. The science of being overshadowed the pure sense of the virgin mother with a full recognition that Spirit is the basis of being. The idea we call Substance, and Mary named Jesus, dwelt forever in the bosom of the Father, in the principle of man, and woman perceived it because of her more spiritual nature. ${ }^{28}$

Eddy credits the Virgin with first recognizing that "Spirit is the basis of being," and she takes that revelation to signal the innate "spiritual nature" of all women, a belief in accord with the bodiless piety characteristic of sentimental femininity. ${ }^{29}$ Moreover, in announcing that she and Mary had both devised and popularized the same belief, Eddy forges an identification with the Virgin Mary that she then unreservedly pursued.

Critics such as Mark Twain balked at Eddy's audacious appropriation of Mary for the aims of Christian Science, but in

\footnotetext{
${ }^{28}$ Quoted in Gill, Mary Baker Eddy, p. 229.

${ }^{29}$ Noble has analyzed the sentimental feminization of spirit and masculinization of the body in Masochistic Pleasures, p. 33.
} 
doing so, Eddy assimilated a key figure of Catholicism and the sentimental imaginary. ${ }^{30}$ In calling herself Mother Mary, she positioned herself as the Virgin's modern-day successor, universal mother to the faithful. Eddy remarked that only one woman in Christianity could be called Mother Mary, a suggestive comment with a number of possible meanings, among them that she had eclipsed Mary in the Christian pantheon, that she herself had birthed Jesus, and/or that she was a latterday incarnation of the Virgin Mother. Eddy also aligned herself with Mary by publishing several revisions of the Magnificat, the prayer the Virgin delivers when she accepts God's call to give birth to Jesus, thereby reenacting and assuming Mary's spiritualized, asexual maternity. The significance of the Virgin Mary in denoting supreme female authority in Christian Science is evident in a bizarre 1890 incident. Josephine Curtis Woodbury, one of Eddy's chief competitors for rank and position in the Christian Science leadership, announced that she had parthenogenetically conceived a child, whom she named Prince of Peace. Woodbury argued that her son's allegedly immaculate conception legitimized Eddy's doctrinal rejection of materiality, but Eddy interpreted Woodbury's public declaration as a direct challenge to her authority as supreme Christian Mother, and she excommunicated Woodbury, who subsequently sued Eddy for libel. ${ }^{31}$

As this remarkable episode shows, sentimental maternity was useful to Eddy in a number of ways. At a time when women did not regularly occupy pastoral positions or claim to be prophets, it offered a beloved and recognizable model of female spiritual governance, a role so compelling that Eddy was unwilling to share it. Hounded by tireless critics who found her leadership, wealth, and independence fundamentally incompatible with traditional femininity, Eddy cast herself as the sentimental

\footnotetext{
$3^{\circ}$ Twain elaborates at great length on Eddy's Mariolatry in Christian Science, with Notes Containing Corrections to Date, pp. 221-23, 334-39.

${ }^{31}$ Parker, "Mary Baker Eddy," p. 15; Gill, Mary Baker Eddy, pp. 439-42. It was widely known that Woodbury's son was the product of an adulterous union, and Eddy charged her with depravity.
} 
mother to soften her public image, endear her to women already conversant with the trope, and affirm her conservative, traditionalist bona fides.

One means by which Eddy affirmed her credentials as a sentimental mother was her celebrated preoccupation with domesticity and proper housekeeping. Because of its concentrated attention to household affairs, sentimentalism has been described as domestic literature, and the central plot of the heroine's spiritual transformation is often effected by means of her education in household management. ${ }^{32}$ An unruly household signals the need for moral reform, as does the disarray of Dinah's kitchen in Uncle Tom's Cabin and the March sisters' domestic struggles in Little Women; conversely, Ruth Hall's clean and cheery household registers her innate goodness, as does Huldy's efficient housekeeping in Stowe's short story "The Minister's Housekeeper."33

Just as sentimentalism teaches the spiritual rewards of a clean, well-ordered home, Eddy encouraged domestic hygiene among Christian Scientists. Renowned for her immaculate housekeeping, she liked to tell stories about her lifelong fastidiousness, such as her childhood inability to fall asleep if she had neglected to arrange her shoes in a neat row. ${ }^{34}$ Although she never formally mandated rigorous housekeeping as a matter of church policy, her example was a sufficient inducement, and the practice quickly became synthesized into Christian Science culture and observance. ${ }^{35}$ In a 1908 monograph, critic Elbert Hubbard, who remarked on Eddy's exemplary housekeeping

\footnotetext{
${ }^{32}$ Mary Kelley's appraisal of sentimentalism's innate domesticity has been most influential. See her Private Women, Public Stage: Literary Domesticity in NineteenthCentury America (New York: Oxford University Press, 1884), pp. x-xii.

${ }^{33}$ Gillian Brown provides a helpful gloss to sentimental domesticity in her Domestic Individualism: Imagining Self in Nineteenth-Century America (Berkeley: University of California Press, 1990), pp. 13-38, 63-95

${ }^{34}$ Gill, Mary Baker Eddy, p. 402.

${ }^{35}$ Hubbard observed this phenomenon with the remark that "Mrs. Eddy does not say much about hot water, soap and clean towels, but the idea, regardless of the non-existence of matter, is fixed in the consciousness of every Christian Scientist that absolute bodily cleanliness, fresh linen and fresh air are not only next to godliness, but elements of it. All of which you could never work out of 'Science and Health with Key to the Scriptures' in a lifetime of study" (Little Journeys, p. 142).
} 
and the readiness with which her followers emulated her, wrote, "As for eating, [Eddy's] table had enough, but stops short of surfeit; the service is dainty; and all these things are seen in the homes of Christian Scientists. Always in the home of a good Christian Scientist the bath room is as complete as the library, and both are models of good house-keeping, seemingly always in order for the inspection committee." 36

On its own merits, Eddy's commitment to a tidy home is not particularly noteworthy, given the commonly recited maxim that cleanliness is next to godliness. Within the context of core Christian Science doctrine, however, it is anomalous. Central to sentimental domesticity is the conviction that caring for physical objects is ethically virtuous, but as Eddy wrote, "whatever is loved materially, as a mere corporeal personality, is eventually lost," a repudiation of materiality fundamentally at odds with a belief in the innate value of housekeeping. ${ }^{37}$ Maintaining that "[d]rugs and hygiene cannot successfully usurp the place and power of the divine source of all health and perfection," Eddy further contested the conventional wisdom about cleanliness. ${ }^{38}$ The body, she insisted, did not require conventional grooming to maintain health or to achieve holiness, but she nonetheless recommended that its environment be cleansed daily.

Although some commentators recognized Eddy's interest in household management, others gleefully repeated rumors about her slatternly homemaking and her selfish neglect of her domestic duties when she was first widowed, a criticism that has proved as enduring as it is petty. ${ }^{39}$ Today a similar accusation would carry little weight, but in the late nineteenth century, this attack on Eddy had the effect of impugning her femininity, morality, and, ultimately, her fitness for religious leadership. In circulating stories about her immaculate housekeeping, Eddy countered her detractors by depicting herself

\footnotetext{
${ }^{36}$ Hubbard, Little Journeys, p. 142.

${ }^{37}$ Eddy, "Retrospection and Introspection," p. 32.

${ }^{8}$ Eddy, Science and Health, 167:12-14.

${ }^{39} \mathrm{~A}$ more recent example of this enduring accusation can be found in Stefan Zweig's Mental Healers: Franz Anton Mesmer, Mary Baker Eddy, Sigmund Freud, trans. Eden and Cedar Paul (Garden City, N.J.: Garden City Publishing, 1932), pp. 111-15.
} 
as scrupulous, fully in accord with sentimental ideology, and therefore as deserving of the supreme rank of church Mother. $4^{\circ}$ Folding domestic language into her doctrinal writing, Eddy affirmed her sentimentalist reverence for the home and depicted Christian Science as an enlargement of that domestic space. For example, in the 1875 first edition of Science and Health, she wrote that " $[\mathrm{h}]$ ome is the dearest spot on earth, and should be the center, but not the boundary of the affections." ${ }^{41}$ Later, in a public address, she declared that the "home of the Christian Scientist is in the understanding of God. His affection and interests are there, and his abiding place is there." 42 By means of such metaphors, Eddy displayed her domestic credentials and appealed to a distinctly sentimental brand of home-based spirituality, thus communicating that her religious leadership had not compromised her domesticity but, instead, had emerged from it.

\section{$\sim$}

Between 1890 and her death in 1910, Mary Baker Eddy retreated to her own home, living in reclusive isolation in rural New Hampshire and refusing not only to make public appearances but also to correspond with anyone outside her inner circle. Her critics contended that Eddy's seclusion revealed her to be self-absorbed and indifferent to her followers, but such assertions failed to take into account the importance of absence to the trope of sentimental motherhood. Although sentimental literature upholds proximity and accessibility as the ideal maternal conditions, separation encourages an idealization of the mother, who thereby becomes an object of worship and fervent longing. Removing herself from public

\footnotetext{
$4^{\circ} \mathrm{Just}$ as Josephine Woodbury challenged Eddy's leadership by emulating the Virgin Mary, another female rival to Eddy's leadership, Augusta Stetson, staked a similar claim by likewise adopting Eddy's language of domesticity, describing the powerful and popular First Church of Christ, Scientist in New York as "home" (Reminiscences, Sermons, and Correspondence: Proving Adherence to the Principle of Christian Science as Taught by Mary Baker Eddy [New York: Putnam, 1917], p. 368).

${ }^{41}$ Quoted in Gill, Mary Baker Eddy, pp. 229-30.

${ }^{42}$ Quoted in Stetson, Reminiscences, Sermons, and Correspondence, p. 368.
} 
view seems to have had just such an effect on Eddy's followers, whose devotion was only deepened by her absence and who construed her withdrawal as a testament to her theological denial of worldliness. In this context, writings about maternal separation such as "Mother's Evening Prayer" become gestures of good faith, tokens of undying love for her figurative children as well as expressions of grief at her estrangement from them. Sentimental maternity also helped to transform this controversial absence into an asset that fortified Eddy's authority. In sentimental literature, the absent mother becomes accessible through the metonymic adoption of her faith and the execution of her religious instructions. That is to say, religious obedience functions in sentimentalism as a conduit for maternal intimacy, a dynamic Eddy instilled in Christian Science. By following Eddy's creed, the faithful could bridge the gap created by her absence and gain access to their loving surrogate mother, a bargain that exchanged spiritual autonomy for discursive maternal care.

Familial metaphors and Eddy's bodily absence also had the secondary but immensely important effect of creating a consensual community of coreligionists, thus enabling Christian Science to assume the community-building responsibilities left unrealized by sentimentalism and to ensure its survival as a denomination after Eddy's death. Family, the building block of community, is typically in disarray in sentimental literature, where it has been dismantled by death, separation, and misunderstanding, and that disruption establishes the conditions of female isolation and vulnerability that the plot then sets out to resolve, often concluding with the heroine's marriage and her re-creation of a household that replaces the parental one that had been destroyed long before. The new conjugal arrangement is often prefigured by a surrogate, spiritual family of fellow believers, as with Ellen Montgomery's multiple adoptions in The Wide, Wide World, the settling of former slaves in Liberia at the close of Uncle Tom's Cabin, and Edna Earl's adoption by Mrs. Murray in St. Elmo.

Models for such spiritual families can be found in early Christian writings, most notably in the episode in which Jesus 
renounces the tribalism of Judaism and urges his followers to form alternative communities bound by shared beliefs. Ellen Montgomery's decision to favor the religious instructions of her adoptive brother (whom she later marries) over those of her biological uncle, for example, recapitulates that supremacy of spiritual kinship. In thus celebrating spiritual community as a replacement for the biological family, however, sentimentalism noticeably withholds guidance on how to form such a surrogate community and depicts it as the result of accidental meetings and chance acquaintanceships rather than deliberate effort. Here, then, Christian Science improved upon its sentimental antecedents, for Eddy's familial rhetoric not only placed Christian Science within a recognizable Christian typology of devotional kinship but also positioned the denomination as the fulfillment of sentimentalist promise by regularizing the protocols of community building and consolation that sentimentalism had left spontaneous and organic. Those who chose to join this new community, in other words, could expect to reap sentimentalism's bounty: a nurturing if absent spiritual Mother, a spiritual epiphany about the ills of materiality, and a community of fellow believers who would offer sympathy and comfort. Just as Jesus, in his death and resurrection, set up a scenario in which the religion he founded could persist in his absence, so Eddy's rhetoric of kinship and motherless children prepared her congregants to endure without her.

The social significance of Christian Science and its appeal to countless followers cannot be separated from its founder's commitment to literary sentimentalism. First and foremost, Eddy's use of sentimental typology helped her create a pioneering institution of female-centered spirituality. In its literary manifestation, the sentimental emphasis on female spirituality had been merely discursive; as institutionalized within the organizational structure of Christian Science, it became doctrinal. In sentimentalizing her own life within the narrative of Christian Science history, Eddy imbued domestic life, motherhood, and maternal love with religious significance, thereby dignifying and elevating female domains long overlooked by America's patriarchal Christian denominations. Moreover, by codifying in church 
bylaws that women assume positions of authority in local congregations as well as at church headquarters, she ensured that sentimental conventions would continue to be reproduced in the religion she had founded.

In the end, Christian Science was Eddy's most popular and influential text. Her curative theology, which taught women to take control of their health and spirituality, extended sentimentalism's self-help tradition but it also rewrote its narrative conclusion, seeking to resolve once and for all the crises of illness, death, and separation intrinsic to the sentimental plot. Thus did Eddy aim to forestall the continued reinscription of sentimental patterns in the lives of her congregants and, in apotheosizing herself as the sentimental grieving mother, to consign sentimental suffering to a distant past commemorated only in religious observance.

Claudia Stokes, an Associate Professor of English at Trinity University in San Antonio, Texas, is the author of WrITERS iN Retrospect: The Rise of American Literary HisTORY, 1875-1910 (2006) and coeditor (with Michael A. Elliott of Emory University) of AMERICAN LITERARY STUdIES: A Methodological REAdER (2003). She is currently at work on a book about the influence of sentimentalism on American organized religions. 